\title{
The Indebted Empire: America's Current-Account Deficit Problem
}

\author{
Iwan Morgan \\ Institute for the Study of the Americas, University of London, 31 Tavistock Square, London \\ WC1H 9HA, UK. \\ E-mail: iwan.morgan@sas.ac.uk
}

\begin{abstract}
America is like no other dominant power in modern history because it depends on other countries for capital to sustain its military and economic dominance. The US current-account deficit, comprised primarily of the trade deficit and interest payments on America's external debt to foreign investors, has ballooned since 1997 to reach an annual rate in excess of 6 percent in mid-2005. The US is tied into a codependency with Asian countries, which fund its borrowing in order that their export-driven economies have the benefit of competitive exchange rates to sell their goods to Americans. Although some analysts have characterized this relationship as Bretton Woods 2, it is inherently unstable. The US requires Asian countries to continue purchasing massive quantities of dollar reserves but their capacity and need to do so are finite. When Asia stops buying dollars, the American economy will experience problems that will have implications for America's global power. To avert this risk, the US needs to reduce its own governmental budget deficit and promote international agreement for currency and other economic adjustments that can help to rebalance trade flows.
\end{abstract}

International Politics (2008) 45, 92-112. doi:10.1057/palgrave.ip.8800147

Keywords: American economy; US deficit; Asia; co-dependency; trade flows; Bretton Woods 2

\section{Introduction}

No sooner has the term 'Empire' entered conventional usage as a descriptor of America's global power in the early 21 st century than sceptics have questioned the sustainability of the American imperium because of its indebtedness to foreign cash and capital. As former Clinton administration Treasury Secretary Larry Summers observed (2004a, 48), 'There is something odd about the world's greatest power also being its greatest debtor.' Former Nixon administration Commerce Secretary and current chair of the Council on Foreign Relations Peter G. Peterson $(2005,12)$ similarly warned that America's need to borrow over two billion dollars every working day in 2004 to cover its current account deficit constituted a level of risk in both economic and national 
security 'that no great power should be taking.' To bullish cheerleaders for the new empire, such doubters are just the latest in a long line of Cassandras who have regularly and wrongly predicted since Circa 1950 that American power would be constrained by economic limits. Two critics of 'the overstretch myth' (Levey and Brown, 2005, 3) have cogently argued that 'the world's appetite for US assets bolsters US predominance rather than undermines it.' In their view America's power is solidly grounded on an economy that is continually extending its lead in innovation and new technology, which makes foreigners want to invest in its success. In light of this debate, this paper seeks to assess the significance of America's indebtedness both to the well-being of its economy and to the foundations of its global power.

In order to contextualize the analysis, it is necessary first to consider the significance of America's economic strength to its broader global power. Empire, of course, is not an uncontested term in the lexicon available to characterize America's position in the international system. 'Hegemon,' 'superpower,' and 'unilateralist' continue to have their devotees, but arguably none of these convey the change in America's view of its world role since the cataclysmic events of $9 / 11$. The Bush Doctrine's arrogation to the United States of the right to set international standards, determine threats - actual and potential, and use force as it sees fit can reasonably be regarded as imperialism howsoever named. (Hitchens, 2002; Shaw, 2002; Cox, 2003, 2004; Ferguson, 2003; Cohen, 2004) But whatever term is used to define American power, it is evident that, in Ikenberry's $(2004,153)$ words, 'the ability of any state to dominate the international system depends on its economic strength.'

First and foremost, economic growth generates the lifeblood of hard power. America's imperial project requires it to bear the costs of the attendant global military liabilities without harm to its economy. During the Cold War the United States built up a huge national security apparatus to sustain global containment of communism for nigh on 40 years, but defence spending actually declined as a share of total output over the course of this conflict thanks to the growth of the giant American economy. During the Reagan defence build-up of Fiscal Years (FY) 1982-1987, national security outlays averaged 6.1 percent of gross domestic product (GDP), well below the Cold War peak of 14.2 percent of GDP in FY 1953. ${ }^{1}$ The strength of the American economy also helped to determine the outcome of this superpower conflict. In the 1980s the Soviet Union's defence budget claimed a proportion of national output between two and three times greater than its American counterpart. Mikhail Gorbachev's recognition that this was unsustainable was instrumental in his decision to pursue a détente that would allow for restructuring of his country's inefficient economy. (Kennedy, 1989; Nye, 1990; Schweizer, 2002)

At first sight America's 21st century imperial grand strategy looks less costly than its Cold War crusade. In FY 2004 the defence budget amounted to \$456 
billion, equivalent to 3.9 percent of GDP, a substantially lower share than in the Reagan era. However, the Bush-initiated defence expansion is set to last far longer than the record continuous expansion from FY 1977 to FY 1989. On a best-case scenario, the Congressional Budget Office (CBO) (2005, 52-53) projected that military spending on current baseline assumptions would dip in FY 2006 and FY 2007 before rising steadily to \$529 billion in FY 2015 and that defence would average 2.9 percent of GDP from FY 2006 to FY 2015. However, the Bush administration's tendency to fund its defence expansion in part through supplemental requests - which accounted for 20 percent of total military spending in FY 2004 - suggests that CBO estimates are short of the mark. ${ }^{2}$ Many analysts (Kady, 2004; Brainard and O'Hanlon, 2004) anticipate that the defence budget will exceed $\$ 600$ billion within a decade because of this and other underestimates. Whatever its true scope, the main expansion will take place from 2010 onwards through the conjunction of new weapons systems (such as the Marine Corps' V-22 Osprey tilt-rotor troop carrier, the Virginia-class attack submarine, and the F-35 Joint Strike Fighter) reaching full production, higher operation and maintenance costs, and pay rises and enhanced benefits to attract and hold military personnel.

Military outlays are not the only source of rising governmental expenditure in the Bush era. Homeland security costs (about a quarter of which are subsumed within the defence budget) are projected to rise from $\$ 36$ billion in FY 2004 to $\$ 50$ billion in FY 2015. (CBO, 2005, 71) However, analysts such as Peterson (2004) contend that the expansion will need to be much greater to deal with weak points in the system. ${ }^{3}$ Moreover, in previous periods of military expansion (World War II, the early 1950s, and the 1980s) domestic programme expenditure was either reduced or its expansion was slowed. By contrast, the early 21 st century economy will have to bear not only the higher costs of defence and homeland security but also significant increases in social security and Medicare as the post-1945 baby-boom generation reaches retirement age from 2012 onward. $^{4}$

The second requirement of economic power is to enable the United States to maintain the liberal economic order of free markets in trade and capital that it created at the end of World War II and has promoted ever since. Like Britain in the 19th century international economy, the United States acted in the second-half of the 20th century as the hegemonic stabilizer who 'resolves the question of which state will govern the system, as well as what ideas and values will predominate, thereby determining the ethos of succeeding ages'(Gilpin, 1981, 203). From Keohane's perspective $(1984,32)$, the hegemonic power had to possess a preponderance of material resources - particularly raw materials, capital, control of markets, and leadership in highly valued goods - in order to make and enforce the rules of the international economy through either coercion or inducement. Of course, hegemony should not be interpreted as 
omnipotence. Even at the height of its relative economic power in the late 1940s, the United States did not always hold sway over very dependent allies (Ikenberry, 1989). As other industrial nations recovered from World War II and new ones rose, America's economic ascendancy inevitably diminished in scope, but the rash of predictions that its power over the international economic system was near its end proved mistaken (Cox, 2001) ${ }^{5}$.

Although the world became more globalized and interdependent towards the end of the 20th century, America exercised what Wade (2003) termed 'empirelike power' over the international economy. In part this reflected its continued ascendancy in terms of tangible economic resources. In overall volume of production and trade, the US is broadly on level terms with the European Union and somewhat ahead of Japan/East Asia, but as neither of these competitors is a single state, they face greater difficulty in devising common policies. America's economy is more than double the size of any other national economy, so it more often initiates policies to which the other two blocs react. Moreover, it holds a strong lead over all countries in the production and application of new information technology; the dollar is the global reserve currency; Wall Street continues to be the heart of the world's financial system; and America's giant domestic market has been a vital piston in the engine of global economic growth, particularly through its capacity to rescue the international economy from stagnation by acting as the importer of last resort (Zuckerman, 1998; Cumings, 1999).

America's authority over the international economic system also reflected its significance as the seemingly indispensable guarantor of order, ranging from its role in ensuring the security of world oil supplies to its broad promotion of open markets. America's ascendancy was not always embraced with enthusiasm; nor was it always unselfishly internationalist and benign (Russett, 1985; Snidal, 1985). Nevertheless the benefits of living under its protection generally outweighed the disadvantages insofar as most other non-communist nations were concerned. When economic disputes with other countries arose, as they inevitably did from time to time, the imbalance of interdependence generally enabled the US to resolve these to its satisfaction through the bargaining process. Although the leading powers in the international economic system became locked together in mutual dependency, the United States tended to be the least dependent member in this relationship and that asymmetry generally acted to its advantage, as was exemplified by Japan's response to the Wall Street crash of October 1987. Amidst growing concern about the impact of the US trade and budget deficits on the dollar's value in mid-1987, lighter than normal Japanese purchases of Treasury bonds helped to push up American interest rates as a premium to cover the added risk. However, Japan's central bank massively increased its security purchases in the wake of the stock market collapse, which many analysts attributed to the fear 
of a dollar-strike by foreigners. As one Japanese financial analyst commented, 'Japanese financial institutions are captives of the American market. When you lend too much money, you have a vital interest in that economy staying healthy, so you have to cooperate'(Nye, 1990, 158).

Finally, America's economic strength not only underwrites its hard power but also 'burnishes the reputation and self-confidence of the country and thus contributes equally to soft power'(Nye, 2002, 125). The well-being of the economy is tied in with the self-identity of Americans as the people of plenty. When it is doing badly, this is strongly reflected in the national mood, as was evident in the 'malaise' of the late 1970s and the inward-looking concerns of the American public in the early 1990s. On assuming the presidency, Ronald Reagan made it his first order of business to rescue the ailing economy as a prerequisite for rebuilding national confidence in America's capacity to win the Cold War. 'Nothing was possible,' he later declared, 'unless we made the economy sound again'(Reagan, 1990, 333). The successful example of its economy operating in accordance with liberal values of market openness, regulatory flexibility, and unrestricted movement of capital also energizes America's efforts to promote the kind of international economic order it prefers. With the conundrum of slow productivity apparently resolved by the high-tech boom of the 1990s, the main concern about the American model centred on its capacity to overcome income inequality rather than to sustain aggregate growth. To many foreigners the benefits of greater reliance on market forces had to be measured against the costs in greater inequality and insecurity for those in the lower half of the income distribution (Hutton, 2002; Stiglitz, 2002; Finnegan, 2003). According to Nye (2002, 132), resolving how 'we deal at home with those who are left behind' was consequently essential to enhance America's soft power.

Nevertheless, the United States in the early 21 st century faces a much greater and more immediate economic problem that is a potential threat to all facets of its power, hard and soft. According to Schwenninger (2004, 129), 'America is like no other dominant power in modern history - because it depends on other countries for capital to sustain its military and economic dominance.' The US current-account deficit, comprised primarily of the trade deficit, interest payments on the America's external debt to foreign investors, and net unilateral transfers (foreign aid and remittances), has ballooned since 1997 to reach a record annual rate of 6.4 percent in the second quarter of 2005 (Bureau of Economic Analysis, 2005). The US current account was usually in surplus every year between 1960 and 1982 (excepting 1971, 1972, 1977 and 1978) but has been in deficit every year but one (1991) since 1982. The post-1997 surge dwarfs the Reagan-era expansion, which peaked at 3.5 percent of GDP in 1987. (McKinnon, 2005) The trade deficit was initially driven by the rising dollar from 1997 onward but has continued 
to grow despite the greenback's decline since 2002 and amounted to $\$ 620$ billion (5.3 percent of GDP) in 2004. ${ }^{6}$ The interest and dividends paid to foreign investors constitute the other key element of the current account deficit. America's net international investment position turned negative in the Reagan era but deteriorated significantly from 1997 from 5 percent of GDP in 1997 to 24 percent of GDP at the end of 2004 . $^{7}$ Simply put, the world's pre-eminent military, geopolitical and economic power is also its largest debtor, which absorbs at least 80 percent of the savings that the rest of the world does not invest at home (Brenner, 2002; Bivens, 2004; Weller, 2004; Rogoff, 2005).

According to some analysts, the US current account deficit is set to expand to 7 percent of GDP in 2006 and in excess of 8 percent in 2008, by when the net investment debt could well equate to about 50 percent of GDP and almost 500 percent of US export revenues. (Roubini and Setser, 2004, 4-5) Even more cautious estimates project that it will reach between 7.5 and 8.5 percent of GDP by 2010 (Godley et al., 2005). There is no absolute threshold at which a country's current account deficit becomes unsustainable. Past trends suggest that these imbalances typically decline, whether due to lower exchange rates or economic slowdown, once they reach 4.2 percent. The US may be able to operate higher deficits because of the dollar's role as international reserve currency, but its capacity to sustain them along the growth track projected is doubtful. Countries whose imbalances provoked financial crisis, such as Sweden and Finland in 1991 and South Korea in 1997, operated deficits of less than 4 percent of GDP. (Mann, 1999; Weller, 2004) Bullish voices rubbish comparisons between the American Gulliver and such economic Lilliputians, but their optimism that the US can ride out its current account shortfalls may have a hollow ring.

Some US Treasury and Federal Reserve officials contend that the currentaccount deficit is a sign of America's economic power, not a symptom of weakness, because the US offers higher investment returns than Europe and Japan. Federal Reserve Governor Ben S. Bernanke, in particular, advanced a 'global saving glut' theory that excess savings in slow-growing industrial economies like Japan and Germany and fast-growing emerging markets like China and India are drawn like bees to the honey pot of America's dynamic economy by its efficient capital markets. (Bernanke, 2005; Miller, 2005; Torres, 2005; The Economist, March 2005b) It was certainly the case that the US benefited from large net inflows of equity, bond and other stock market investment in the boom times of the late 1990s, but private investment declined thereafter because of diminishing returns, resulting initially from stock market decline and then the falling value of the dollar. The continued growth of the net external debt in these circumstances reflected increased purchase of Treasury securities by foreign central banks to reap the competitive trade advantages of 
slowing the momentum of the dollar's decline against the values of their own currencies (Garten, 2004; Cline, 2005; Labonte, 2005; McKinnon, 2005).

The full extent of foreign central bank purchase of Treasury bills is a matter of dispute but in all probability the volume is significantly higher than recorded holdings, in part because securities bought for central bank clients through brokers are counted as private sales. Nevertheless, there is universal agreement that recent purchase of reserves by central banks is unprecedented in scale. According to The Economist (2004), global foreign-exchange reserves in all currency denominations rose by some $\$ 1$ trillion in value in the 18 months between June 2003 and December 2004. In comparison, it took a decade to accomplish the previous addition of $\$ 1$ trillion to official reserves. Asian central banks, led by Japan and China, have been at the forefront of this development. Japan's reserve holdings mushroomed from $\$ 220$ billion to $\$ 834$ billion and China's grew even more exponentially from $\$ 143$ billion to $\$ 610$ billion from 1997 to 2004. The bulk of this accumulation has been in purchase of dollar reserves, including Treasury securities, which increased by an estimated \$1092 billion in the 3-year period from 2002 to 2004. Japan provided about $\$ 200$ billion of the $\$ 485$ billion in reserve financing that the US obtained in 2003, while about 75 percent of China's reserve holdings were in dollars at the end of 2004. Foreign central banks purchased in the order of 80-90 percent of the new net supply of US Treasuries between the start of 2000 and the end of 2004, by when their total share of these securities may well have been as high as 40 percent (Roubini and Setser, 2004, 2005; Higgins and Klitgaard, 2004; Samuelson, 2005) ${ }^{8}$.

With East Asian countries accounting for 80 percent of central bank purchases of dollars and Treasury securities in the last two quarters of 2004, Dooley et al. (2004a, 2004b) argued that the United States had become locked with them into a mutually profitable and therefore stable co-dependency arrangement that amounted to a new version of Bretton Woods. Since the benefits of stable, weak exchange rates exceed the costs of reserve accumulation in their case, the industrialized and industrializing Asian economies formally or informally tied their currencies to the dollar to power their export-led growth. Asian reserve accumulation in turn frees the United States from having to raise interest rates, which consequently allows it to run big budget deficits and drive its own economic expansion by sustaining demand from debt-laden consumers through the instrumentality of cheap credit.

The 'Bretton Woods 2' theorists expected the system to remain intact for a generation, the time they estimated that China would require to absorb its surplus rural labour into a modern industrialized economy. More pessimistic assessments (Roach, 2004; Roubini and Setser, 2005, 3-4) envisage the system unravelling before 2010 because of its inherent instability. Since the Asian countries' export boom is currency-manipulated, it does not have stable 
foundations in terms of enhanced productivity and efficiency, but depends instead on circumstances that are subject to change - the maintenance of favourable exchange rates with the dollar and the capacity of American consumers, many of them debt-laden, to absorb more and more goods. Moreover, Asian central banks held some 60 percent of global foreignexchange reserves by late 2004, a portion well in excess of Asia's shares of global trade and global GDP. If the US current account deficit continues to grow at its present rate, the scale of financing required to sustain it could well exceed the absorption capacity of Asian central banks for dollar holdings. ${ }^{9}$

Although otherwise sceptical of the possibilities of US empire, Michael Mann regards America's indebtedness 'as a sign of strength, giving it a unique degree of financial freedom' $(2004,58)$. In his view, it enables the US to run up enormous military spending without risk of the kind of fiscal overstretch that plagued earlier empires. Similarly, Mead (2004a) coined the term 'sticky power' to conceptualize the American-Asian co-dependency as asymmetrically tilted in favour of the United States on grounds that the giant American economy had attracted the East Asian countries into its sway and then trapped them there. In his view, all America's trading partners had acquired a strategic interest in maintaining its economic well-being because this is integral to their own prosperity. Under those circumstances, Mead argued, 'debt becomes a strength, not a weakness... . Like Samson in the temple of the Philistines, a collapsing US economy would inflict enormous, unacceptable damage on the rest of the world. That is sticky power with a vengeance'(2004b). However, this attempt to define a new dimension of power arguably underestimates the problematic implications of America's indebtedness for the more orthodox forms of its power.

In contrast to the situation in the early stages of global economic interdependence in the late 20th century, America may well be the more vulnerable partner in its relationship with East Asia, which Summers has characterized as 'the balance of financial terror'(2004b). As America's external debt grows, it becomes ever more exposed to the possibility of what Schwenninger (2004) dubs its 'Suez moment.' In 1956, Britain had to call off its ill-advised military campaign with France and Israel to regain control of the Suez Canal from Egyptian nationalization because of the monetary crisis provoked by America's refusal to support the pound in the face of a run against sterling. In a worse-case scenario the US in turn could find its options in dealing with China with regard to Taiwan or North Korea constrained by its dependency on Beijing's continued purchase of its Treasury securities. Moreover, if the US came to regard China as a strategic threat in East Asia, its capacity to enhance its regional security interests would encounter the paradox of partial dependence on China's ongoing funding of its defencerelated deficit spending. Even without a geopolitical crisis, America is 
vulnerable to internal developments in China and Japan over which it has little or no control. Both countries have weak banking systems plagued by bad loans that are unlikely ever to be repaid. It has also long been feared that the Japanese bond market is a bubble waiting to burst. A banking or financial crisis in either China or Japan, by no means an implausible eventuality, could have severe repercussions for the United States.

It is not necessary to rely on hypothetical cases to indicate the erosion of America's power as a result of its indebtedness. Desperate to reduce its trade deficit, the United States has vainly tried since 2003 to get the Chinese to revalue their currency by at least 10 percent. America has effectively counted on a steady devaluation of its money against other currencies to fund its burgeoning trade deficit. Profiting from the dollar's status as global reserve currency, it can buy from overseas, pay in dollars, and then print more dollars to replace those shipped abroad. The resulting inflation of the US greenback reduces the value of the trillions of dollars held in foreign accounts. According to Bonner and Wiggin $(2006,37)$ '[This] is a form of imperial tribute. It is America's only way of making the empire pay.' China's policy of pegging its currency to the dollar since 1997 not only safeguarded the competitiveness of its products in the American market but also provided automatic relief from payment of this tribute. US policymakers bristled at what they deemed a violation of free trade principles but which was in reality just a more direct form of currency manipulation than their own. However, they lacked the muscle - political or economic - to compel Chinese obeisance on the issue of renminbi revaluation.

When President Bush raised the issue with his Chinese counterpart, $\mathrm{Hu}$ Jintao, at the Asia Pacific Economic Conference in October 2003, he received a firm rebuff (Denny, 2003). Nor did the Americans get any further by enlisting the support of G-7 partners at their Washington meeting in October 2004. Attending this body for the first time, Chinese officials insisted that there would be no early currency revaluation in spite of western demands (Heath, 2004). The same response greeted entreaties from White House envoys, IMF delegations, and American corporate leaders who visited Beijing. 'The Chinese have got the US by the throat,' declared William Barron, managing director of Deutsche Asset Management in London, 'When China stops buying dollars, the age of cheap capital is over' (Glain, 2004, 45).

US leaders took heart that their entreaties had paid off when Beijing appeared to change course in July 2005. The People's Bank of China (PBoC) announced that it would allow the renminbi to appreciate by 2.1 percent against the dollar and would adopt a so-called 'crawling peg' strategy of letting it move by up to 0.3 percent daily against a 'basket' of different currencies. It soon became evident, however, that this revaluation was a signal of China's growing power in the global economy rather than evidence of America's 
capacity to set international rules. As Standard Chartered chief economist Gerard Lyons commented, '[E]ven though the dollar is still the world's premier currency, it is clear that Asia now holds the key' (Stewart, 2005). The PBoC specifically warned that the very modest dollar-renminbi adjustment was not the first step in a rolling devaluation, but US Treasury Secretary John Snow optimistically hailed its significance as evidence of Chinese willingness in principle to accept that market forces should determine currency values (Balls and Beattie, 2005). Within a matter of months, however, he was calling for the PBoC to widen the renminbi's trading band because early expectations that its value would be periodically readjusted had not been fulfilled. On the other hand, Snow effectively acknowledged that the United States had little option but to continue with patient diplomacy to make the Chinese more pliable because, as he put it, 'they don't respond very well to threats' (Balls and Alden, 2005). This was a direct reference to pending congressional consideration of a number of bills that sought to impose tariffs as high as 27.5 percent on Chinese imports unless Beijing shifted to greater currency flexibility.

The durability of the Bretton Woods 2 system ultimately depends on Asian countries continuing to finance the US external debt because the consequences of not doing so would be as bad or worse for their own economies as for America's. However, the United States has a particular disadvantage because it lacks proactive capability to maintain that particular balance of financial terror. In other words, it is dependent on the strategic assessment by Asian countries of the ongoing benefits of funding its borrowing. The possibility of a change of approach on their part is not so far-fetched because the balance of interests is very much in a state of flux.

The short-term nature of so many Treasury securities means that buyers have flexibility and sellers become increasingly dependent on new issues being taken up. ${ }^{10}$ The exponential growth of America's borrowing requirements will also test the dollar absorption capability of Asian countries that have already made massive reserve purchases. Moreover, countries that are not sufficiently diversified in their reserve holdings may not want the risk of buying more American assets. On February 21 2005, South Korea's central bank, most of whose \$200 billion of foreign reserves were held in dollars, announced that it planned to diversify from that currency. In combination with concern about inflation and rising oil prices, this spooked a fall of 174 points on the Dow index and a marked slide in dollar (The Economist, Feb. 2005a). Although South Korea later clarified that it would only slow down dollar purchases, not sell off existing holdings, the episode was indicative of America's vulnerability to decisions taken by foreigners. Other holders of dollars, notably Indonesia, Malaysia, Thailand and Russia, have also indicated that they wish to diversify their reserves away from the greenback. If a single country began a substantial defection, others might follow. This is what happened in 1968, when France 
turned its surplus dollars into gold under the old Bretton Woods fixedconvertibility arrangement, which served to plunge Lyndon Johnson's administration into a financial crisis (Eichengreen, 2004). Moreover, Asian private investors whose holdings of American assets are predicated on the assumption that currency intervention will continue to limit the dollar's decline would likely replicate any significant defection by Asian central banks unless US interest rates were raised significantly to compensate for the greater risk.

In recognition of America's vulnerability, the Bush administration resorted to a dollar-devaluation strategy to reduce the US trade deficit. According to one analyst (Bergsten, 2004, 93), the dollar needed to decline through market correction by 25 percent from its early 2002 peak. Although the US persuaded the G-7 finance ministers in June 2003 to agree that exchange rates would be left to the market, its trade gap continued to grow. The main impact of market correction fell on the euro, the Canadian dollar and the British pound, which appreciated in value to the dollar by 30,22 and 20 percent, respectively, from early 2002 to 2004 . However, the bulk of America's trade deficit is with Asia, and particularly China. In the same period the greenback remained constant against the renminbi because of the fixed exchange rate operated by the Chinese government and fell by only 17 percent against a basket of currencies of other Asian countries, whose central banks entered the foreign exchange markets to moderate the bilateral depreciation of the dollar against their currencies (Labonte and Makinen, 2004; The Economist, 2004).

Of course, the United States has to be careful what it wishes for with regard to currency adjustment in case it provokes a dollar-strike. If China were to allow its currency to float in response to market forces, its central bank would have less cause to maintain, let alone expand, its dollar holdings that are so fundamental in financing the US external debt. A 20 percent rise in the renminbi's exchange rate relative to the dollar would wipe about $\$ 100$ billion off the value of the dollar reserves held by China in 2005, equal to 6 percent of its GDP (Setser and Roubini, 2005, 196). It is also the case that the longer China continues to fund US borrowing, the larger will be its ultimate losses in the event of a substantial dollar devaluation. To date, however, China has suffered very little loss in the value of its dollar holdings in comparison with those Asian countries whose currencies have proved more volatile against the dollar than the renminbi. Continued decline of the dollar could put one or more of the latter in a position where their reserve losses outweighed the benefits of funding America's borrowing.

The weakest link in this regard may be Japan, which engaged in massive currency manipulation in 2003-2004 to sustain recently revived economic growth through moderation of the yen's appreciation against the dollar. Speculation has mounted that the visit of Ben Bernanke to Tokyo in May 2003 was instrumental in securing agreement for concerted action by the American 
and Japanese governments to prevent a private sector run against the dollar. The combination of Bush administration tax cuts and Federal Reserve easy credit ensured that US consumers could maintain consumption levels. Meanwhile, the Bank of Japan (BoJ) effectively created 35 trillion yen, the largest single monetary creation in peacetime in world history, to buy dollars accumulated by Japanese citizens from trade with and investment in the US. Whether or not undertaken as part of a deal with the Americans, some financial analysts regard the BoJ's willingness to loan the equivalent of $\$ 320$ billion to the United States as the most important factor in the global economy attaining its fastest growth rate for 30 years in 2004. In the words of one, it represented 'the difference between global reflation and global deflation' (Duncan, 2005). However, the BoJ's intervention only slowed rather than reversed the rise of the yen against the dollar. With Japan's currency undergoing a 5-6 percent annual appreciation since the dollar was at peak value, it could yet become the first nation seriously to reassess the profit/loss consequences of sustaining America's external debt (Roubini and Setser, 2004; Pesek, 2005).

Besides currency devaluation to improve trade flows, enhancement of national saving - composed of business, household and government (federal, state and local) savings - is the only way that the US can lessen its dependence on foreign capital. Since Americans' propensity to consume reflects their selfidentity as a people of plenty, their optimism about everlasting economic growth, and their confidence in the munificence of social security benefits to underwrite their economic security in old age, there is no proven policy available to increase household saving. As Americans went on a binge of consumption in the last boom of the 20th century, the personal savings rate dropped from its already low level but this was mitigated by public governmental surpluses in the second-half of the 1990s. In the early $21 \mathrm{st}$ century, however, the combination of low household savings and the return of federal deficits has driven the national savings rate down to a record low of 1.2 percent of GDP in 2004, the lowest of any industrial nation. To correct this, the federal government needs to get its financial accounts back into the black (Gilpin, 2000, 345-346; Rubin et al., 2004; Gale and Orszag, 2004; Cline, 2005).

George Bush's commitment to reduce this deficit by half in his second term is intended to set this fiscal conversion in train, but there are flaws in the administration's budget plan. Official projections that show a deficit decline assume that the temporary tax cuts of 2001 and 2003 will expire as scheduled by current law. Were these made permanent in accordance with the president's wishes, the resultant revenue loss would expand the deficit beyond $\$ 600$ billion in FY 2014. Moreover, administration projections for second-term deficit reduction do not factor in the cost of providing middle-class taxpayers relief from the Alternative Minimum Tax, which targets high-income earners who 
aggressively shelter their income. The administration's practice of funding defence through supplemental appropriations will also saddle the budget with hidden extras. True to form, it sent Congress in February 2005 a supplemental request of some $\$ 80$ billion, mainly to cover war spending. This appropriation pushed up Iraq conflict costs beyond $\$ 200$ billion, a bill that many analysts expect to double by the time that the US finally withdraws. For its final piece of wishful thinking, the Bush plan estimates that the bulk of budget savings will be achieved by cutting the discretionary domestic budget in FY 2006 and keeping it flat for the next 4 years. No administration since 1945 has previously succeeded in keeping the lid on domestic appropriations for such a prolonged period. Nor has any administration faced the need for emergency domestic spending of the scale required for Gulf Coast reconstruction in the wake of Hurricane Katrina and the flooding of New Orleans (Collender, 2005; Congressional Research Service, 2005a; Concord Coalition, 2005; Centre on Budget and Policy Priorities, 2005; Weisman and Baker, 2005).

There are two optimistic scenarios with regard to the continuation of the Bretton Woods 2 system. In geopolitical terms, it can be seen as a broadly acceptable - and therefore sustainable - formula for financial burdensharing in the new international order that is emerging to wage the global war on terror. However, as Roubini and Setser argue (2005, 47), the two models of Bretton Woods are fundamentally different because the US did not fund the Cold War by placing large amounts of debt abroad, operating huge budgetary deficits on a long-term basis, and running current account deficits. Moreover, the ties that bind the US to countries that are financing it today, most notably China, are not as strong as those that linked it to its European allies after 1945. Nor are there solid grounds for hope that Europe would step into the breach to rescue America if Asia bailed out. The eurozone has already paid its dues in the form of uncompetitive exports for the rise of its currency against the dollar and the pegged Chinese renminbi, so its leaders are unlikely to take on the additional burden of stocking up on dollar reserves that are bound to decline in value.

If the geopolitical case is not persuasive, the maintenance of Bretton Woods 2 becomes dependent on the economic self-interest of Asian countries to continue funding American borrowing - but self-evidently they cannot do so indefinitely. The best hope for a soft landing is that they prop up the system long enough for the process of global adjustment to take place. This requires America not only to rein in its own consumption, both private and public, but also to expand its exports so that closure of the trade gap is not overly dependent on the declining dollar, with all its attendant risks. For their part, the Asian countries will have not only to continue funding America's currentaccount deficit in the face of inevitable losses as the dollar adjusts but also to substitute their propensity to export with one of consumption to buy US 
goods. The prospects of all these conditions being met as a matter of course are to say the least questionable. As Brian Reading of Lombard Street Research has observed, Bretton Woods 2 is a marriage of convenience rather than a formal arrangement and is therefore less stable than its predecessor. In his words, 'It is more like late Bretton Woods than early, but worse' (Elliott, 2004).

If America is, as Peterson argues (2004), 'riding for a fall,' the hard landing could take place in one of two ways. If nothing else were to change, America's borrowing would continue until foreigners accumulated all the American assets that they wanted. Optimists who scoff that such a scenario is fanciful because a foreign sell-off would result in a self-wounding dollar depreciation overlook the reality that foreigners would only need to slow their dollar purchases to cause the US financial distress. In that event, interest rates would have to rise (which would squeeze investment) and the dollar would decline (which would throttle imports). These developments would result in gradual closure of the current-account deficit to an acceptable level at which foreign holdings would stabilize as a share of GDP. Without a corollary improvement in the fiscal situation to boost national savings, America would then have to get by with less investment in its own economy, leading to a slowdown in the growth of the economy and of the nation's living standards.

The more worrying scenario is a foreign dollar-run far worse than the four experienced by America in the last 30 years (1971-1973, 1978-1979 1985-1987 and 1994-1995). The consequences would be deleterious for consumer and investor confidence, leading almost certainly to both a serious recession in the United States and a slowdown in the global economy. Economic contraction would have the corollary effect of enlarging the fiscal deficit. This would likely compel the federal government to undertake a review of its spending, from which even defence could not expect to be sacrosanct. The experience of the mid-1980s and early 1990s also indicates that protectionist pressures tend to grow when the US economy is undergoing problems. The introduction of a number of bills in Congress in 2003-2004 to impose a broad import levy on China's goods as punishment for its refusal to allow currency flexibility conforms to this trend ${ }^{11}$ (Goldstein, 2004; Congressional Research Service, 2005b). If domestic pressures led to adoption of protectionist polices, other nations would retaliate, thereby raising the spectre of a trade war between competing global blocs. Such a development would have serious consequences for America's hard and soft power because it would effectively undermine the liberal economic international order that the US seeks to promote and the image it projects as the main exemplar of the benefits of free markets. Amidst all this, the other casualty of foreigners no longer needing dollars would probably be the weakening of the greenback's status as the pre-eminent global reserve currency, which has hitherto facilitated America's ability to borrow 
from abroad and has provided an important advantage in its leadership of the world economy.

America's capacity to confound the doomsayers and to renew itself in the face of economic problems, actual and potential, should never be underestimated. Instead of the 'day of reckoning' (Friedman, 1988) that was supposed to result from the fiscal excess of the 1980s, the United States was propelled by the high-tech new economy into the biggest boom in its history in the 1990s. The US economy proved its resiliency once again in 2005, a year of strong economic growth (4.2 percent) despite interest rate hikes, the worst hurricane damage on record, and rising gasoline prices. Moreover, foreigners in general and East Asian central banks in particular continue to show an insatiable appetite for US dollars. In these circumstances it is hardly surprising that the chorus of doomsayers of economic dislocation ahead is at least matched by the optimistic voices singing of sustained economic well-being (Behravesh, 2006; Seager, 2006).

Nevertheless, things that cannot go on forever tend not to, and there is broad recognition that the US current account deficit falls into that bracket. The best that can be hoped for as a denouement is a soft landing for the US economy as America's foreign indebtedness diminishes. Trusting in this outcome involves a risk whose dimensions are disputed. Those who downplay the likelihood of severe disruption find comfort in a basic assumption of economic theory that market actors behave rationally (Labonte, 2005). In other words, foreigners would not stock up on dollars if they expected to have to off-load them quickly at heavy loss in the future and thereby cause the downfall of US consumption that is the engine of global demand. At the other extreme, pessimists worry that the risk of foreign central banks cutting back on their dollar purchases as the greenback declines in value is very real, with the consequence that private foreign investors would seek the security of very high interest rates to step into the breech. Since the US economy has become heavily leveraged with debt, both domestic and external, some analysts fear that large interest rate hikes would have very harmful effects on its well-being. Typifying this view, former Federal Reserve chair Paul Volcker assesses the odds of a severe financial crisis before the end of the first decade of the 20th century as 75 percent likely (Concord Coalition, 2004; Setser and Roubini, 2005).

Under the aegis of the Bush Doctrine, the necessity of pre-emptive intervention to safeguard America's security in the war on terror has become a cardinal principle of US foreign policy. In these circumstances, the reluctance of US policymakers to take pre-emptive action against threats to the nation's economic security is difficult to justify. It is far more rational for the United States to avert a potential economic crisis than run the risk of dealing with the consequences of a real one. The vulnerabilities associated with the current account deficit also go beyond domestic economic concerns. The implications 
for American global power are significant because creditors are usually advantaged over debtors in international politics. Although the Beijing regime has shown no inclination to date to exploit its status as America's creditor, the continuation of their grossly unbalanced financial relationship could exacerbate broader tensions likely to accompany China's rise to global power. The threat of a Chinese dollar-strike would also have to be factored as a possible cost of any US foreign policy that Beijing opposed. Moreover, China can reap the political benefits of the global investor role once played by the United States to forge new relationships with states that are rich in energy and other natural resources, even if their governments - like that of Iran - are outcasts in the eyes of Washington.

Short-term alleviation of America's dependency on foreign capital most obviously requires the United States to reduce significantly its budget deficit (Cline, 2005). This would entail either having to spread the costs of retrenchment across the entire range of fiscal programmes or making painful choices between guns and butter (tax cuts, middle class entitlements and pork barrel projects). Such a fiscal review could have serious implications for America's capacity to sustain the kind of defence establishment required for the global reach of empire. However, a lasting solution to the current-account problem also requires the diminution of America's huge trade gap (Godley et al., 2005). ${ }^{12}$ The experience of the early 21 st century indicates the need for a better balance of trade flows in the global economy of interdependence. One option that the US could pursue to this end would be to promote acceptance of institutional mechanisms limiting exchange rate deviations from their equilibrium values through close cooperation between economic policymakers in industrial and industrializing countries. The re-balancing of the global economy would also benefit from closer coordination of fiscal and monetary policy by key actors that would result in restrictive measures in the United States to encourage production and exports and expansionary measures in many other countries to stimulate demand and imports. Of course, this would be a case of America having to promote its interests through negotiation and compromise rather than imperial fiat. If followed through, therefore, the domestic fiscal and the international economic adjustments necessary to redress the current-account problem could lay bare the contradictions between America's new empire project and its status as the world's largest debtor.

\section{Notes}

1 In constant (FY 2000) dollars, defence spending amounted to $\$ 416.1$ billion in FY 1953, the second highest of the Cold War era after the Vietnam war peak of $\$ 420.1$ billion (9.4 percent of GDP) in FY 1968. Using the same index, expenditure averaged only $\$ 350$ billion in the Reagan build-up and amounted to \$404.7 billion in the Bush FY 2004 budget. However, the FY 1953 and FY 1968 defence budgets were followed by periods of military retrenchment. The Reagan 
build-up was part of the longest sustained military expansion in US history. Defence spending rose in constant dollar terms in every budget from FY 1977 to FY 1989. (Office of Management and Budget, 2005, 111-115)

2 Supplemental appropriations for federal spending averaged $\$ 120$ billion a year - mostly for defence and homeland security - from 2003 to 2005, compared with the average of \$14 billion a year from 1975 to 2002. The increasing reliance on supplemental spending, one analyst noted, frees the White House and Congress from 'all semblance of hard forecasting.' (Cranford, 2005)

3 According to Peterson (2004, 114-116), the US needs to spend additional funds beyond the FY 2004 level as follows: $\$ 62$ billion over 5 years to train and equip police, fire and emergency service first-responders to terrorist attack; \$36 billion over 5 years to improve health-care capabilities in readiness for a terrorist nuclear or biological attack; '\$20 billion upfront, with an unknown yearly investment after that' to reduce the threat of terrorist concealment of nuclear or biological weapons in cargo containers entering the United States; and an unspecified amount to safeguard critical infrastructure.

4 According to official estimates (CBO, 2005, 52-58), mandatory spending on Social Security, Medicare and Medicaid will increase about 7 percent in aggregate every year and rise from 8.4 to 10.4 percent of GDP from FY 2006 to FY 2015. Owing to an ageing population, rising medical costs, and the prescription drug benefits enacted in 2003, Medicare will be the fastest growing of these programs, rising from 2.6 to 3.9 percent of GDP.

5 Among the first significant expositions of relative US decline was Richard Nixon's so-called 'Kansas City doctrine' of 1971 (Nixon, 802-813), which promulgated the emergence of a multipolar world order based on five 'great power centers... . [measured] in economic terms and economic potentialities' - the US, Western Europe, Japan, the Soviet Union and China '[which] will determine the economic future and, because economic power is the key to other kinds of power, the future of the world in other ways in the last third of this century.'

6 Using its 1973 value as 100, the real, broad, trade weighted value of the dollar averaged 91 and America's current account deficit averaged a manageable 1.6 percent of GDP from 1987 to 1997. Between January 1997 and 2002, the dollar index rose from 90.5 to 113 and the current account deficit deteriorated from 1.8 to 4.3 percent of GDP.

7 US foreign liabilities exceeded assets by $\$ 2.1$ trillion by the end of 2004. Yet in spite of a cumulative current account deficit of 14.5 percent of GDP over 3 years, its negative asset position had remained virtually unchanged since 2001, thanks to price and exchange rate changes. Moreover, all the deterioration in the net asset position had taken the form of financial investment, whereas the net stock of direct investment has been close to zero over the last 20 years. The return on direct investment abroad has been much higher than that in the United States, so the net flow of investment income has continued to be positive in America's favour in spite of the asset deficit (Godley et al., 2005; Labonte, 2005).

8 Despite the massive purchase of American greenbacks, dollar holdings have declined as a proportion of total global reserves from around 80 percent in 1975 to 63.8 percent in February 2004, when the balance was made up by the Euro (19.7 percent), the yen ( 4.8 percent), the pound (4.4 percent) and others (7.2 percent).

9 According to one of the most pessimistic projections, Asian central banks would need nearly to double their reserve holdings between the end of 2004 and the end of 2008 to support the projected deterioration in US external balances. In that event, Chinese and Japanese combined reserves would need to expand from an estimated \$1.4 trillion to nearly \$3 trillion over the same period, implying an annual increase of more than $\$ 350$ billion (Roubini and Setser, 2004, 5-6).

10 Central bank demand made it easier for the US Treasury to shorten the maturity of its debt stock through elimination of the 30-year bond and diminution of the supply of the 10-year bond. The US reduced the share of these longer Treasuries in the total marketable stock from 40 percent in 2001 to 31 percent at the end of FY 2004. The overall stock of marketable Treasuries 
expanded by $\$ 931$ billion from FY 2002 to FY 2004, but the longer bond stock only expanded by $\$ 35$ billion (instead of $\$ 365$ billion if their share of stock had remained constant) (Roubini and Setser, 2005, 10).

11 For an analysis of these bills, see Congressional Research Service (2005b), China-US Trade Issues: 14-15. On April 6, 2005, the Senate voted 67-33 against tabling a proposed amendment to the Foreign Affairs Authorization Act to impose a 27.5 percent tariff on Chinese goods if China failed to let its currency appreciate to market levels. Senate Republican leaders headed off a larger rebellion by agreeing that a similar proposal should be brought to a vote no later than July 27, 2005 on condition that its sponsors agree to desist from introducing further initiatives of this kind for the duration of the 109th Congress. Supporters of the measure, led by Charles Schumer (Democrat - New York), agreed on June 30 to delay consideration of the bill after they were briefed by Administration officials that China was expected to make significant progress on currency revaluation in the coming months.

12 Godley et al. $(2005,1,9)$ argue that if the trade deficit does not improve, America's net asset position will continue to deteriorate and the current account deficit will grow. In their view, if the current account deficit rose to 8.5 percent and net private investment were at zero (it turned negative in mid- 2005 because of a massive increase in net lending to the private sector, driven by the real estate boom), it follows as a matter of accounting logic that the government deficit would have to increase to 8.5 percent of GDP in order to sustain full employment. This would result in the long run in the public debt rising to 150 percent of GDP, well over double the current level. The only way of averting this, other than to accept economic stagnation, would be through a sustained increase in net export demand.

\section{References}

Balls, A. and Beattie, A. (2005) 'US Treasury Welcomes Currency Reform', Financial Times, July 22, p. 10.

Balls, A. and Alden, E. (2005) 'FT Interview - US Treasury Secretary: Snow urges China to Show Flexibility by Widening Renminbi Trading Band', Financial Times, November 4, p. 6.

Behravesh, N. (2006) 'The G Shock Absorber', Newsweek, January 16, p. 47.

Bergsten, C.F. (2004) 'Foreign economic policy for the next president', Foreign Affairs 83(2): $88-101$.

Bernanke, B.S. (2005) 'The Global Saving Glut and the US Current Account Deficit', The Sandridge lecture, Virginia Association of Economics (March 10)www.federalreserve.gov/.

Bivens, L.J. (2004) 'Debt and the Dollar: The United States Damages Future Living Standards by Borrowing Itself into a Deceptively Deep Hole', EPI Issue Brief 203, December 14, http:// www.epinet.org/content.cfm/Issuebrief203.

Bonner, B. and Wiggin, A. (2006) Empire of Debt: The Rise of an Epic Financial Crisis, Hoboken, NJ: John Wiley.

Brainard, L. and O'Hanlon, M. (2004) 'Reassessing National Security', in A.M. Rivlin and I. Sawhill (eds.) Restoring Fiscal Sanity: How to Balance the Budget, Washington DC: Brookings Institution, pp 56-77.

Brenner, R. (2002) The Boom and the Bubble: The US in the World Economy, London: Verso.

Bureau of Economic Analysis (2005) 'US International Transactions: Third Quarter 2005', December 16,www.bea.gov.

Centre on Budget and Policy Priorities (2005) Where Would the Cuts be Made in the President's Budget?, February 28 Press Release.

Cline, W. (2005) The US as a Debtor Nation, Washington, DC: Institute for International Economics. 
Cohen, E. (2004) 'History and the hyperpower', Foreign Affairs 83(4): 45-64.

Collender, S. (2005) 'Budget Battles: Crocodile Shock', http://nationaljournal.com/collender.htm', February 15.

Concord Coalition (2004) Facing Facts: The Truth about Entitlements and the Budget October 18.

Concord Coalition (2005) The President's Fiscal Year 2006 Budget: As Significant for What It Omits as for What It Includes February 15.

Congressional Budgetary Office (2005) The Budget and Economic Outlook: Fiscal Years $2006-2015$.

Congressional Research Service (2005a) Report for Congress: The Costs of Operations in Iraq, Afghanistan, and Enhanced Security.

Congressional Research Service (2005b) China-US Trade Issues.

Cox, M. (2001) 'Whatever Happened to American Decline?: International Relations and the New United States Hegemony', New Political Economy 6(3): 311-340.

Cox, M. (2003) 'The empire's back in town: or America's imperial temptation - again', Millennium: Journal of International Studies 32(1): 1-27.

Cox, M. (2004) 'Empire?: The Bush Doctrine and the Lessons of History', in D. Held and M. Koenig-Archibugi (eds.) American Power in the 21st Century, Cambridge: Polity Press, pp. 21-51.

Cranford, J. (2005) 'The Deficit's Hard Truths', CQ Weekly, September 26, pp. 2554-2561.

Cumings, B. (1999) 'Still the American Century', in M. Cox, K. Booth and T. Dunne (eds.) The Interregnum: Controversies in World Politics, Cambridge: Cambridge University Press, pp. 271-300.

Denny, C. (2003) 'Trap a dragon, Mr Bush, and Lose an Election', The Guardian, November 3, p. 25.

Dooley, M., Folkerts-Landau, D. and Garber, P. (2004a) 'The Revived Bretton Woods System: The Effects of Periphery Intervention and Reserve Management on Interest Rates \& Exchange Rates in Centre Countries', National Bureau of Economic Research Working paper No. 10626 (March).

Dooley, M., Folkerts-Landau, D. and Garber, P. (2004b) 'The Revived Bretton Woods System: Alive and Well', December, http://www.frbsf.org/economics/conferences/0502/TheCosmic.Pdf.

Duncan, R. (2005) 'How Japan Financed Global Reflation', FinanceAsia February, http://www. financeasia.com/.

Eichengreen, B. (2004) Global Imbalances and the Lessons of Bretton Woods, National Bureau of Economic Research Working Paper No 10947 (May).

Elliott, L. (2004) 'There Can Be No Soft Landing', The Guardian, September 20, p. 27.

Ferguson, N. (2003) 'Hegemony or empire?' Foreign Affairs 82(4): 154-161.

Finnegan, W. (2003) 'The Economics of Empire: Notes on the Washington Consensus', Harper's Magazine, May, pp. 37-45.

Friedman, B. (1988) Day of Reckoning: The Consequences of American Economic Policy Under Reagan and After, New York: Random House.

Gale, W. and Orszag, P. (2004) 'The US Budget Deficit: on an unsustainable path', New Economy 11(4): 236-242.

Garten, J. (2004) 'The Dollar Adrift', Newsweek, February 9, pp. 40-41.

Gilpin, R. (1981) War and Change in World Politics, New York: Cambridge University Press.

Gilpin, R. (2000) The Challenge of Global Capitalism: The World Economy in the 21st Century, Princeton: Princeton University Press.

Glain, S. (2004) 'The Almighty Yuan', Newsweek, October 4, pp. 44-45.

Godley, W., Papadimitriou, D., Dos Santos, C. and Zezza, G. (2005) The United States and Her Creditors: Can the Symbiosis Last?, The Levy Economics Institute of Bard College (September), http://www.levy.org/. 
Goldstein, M. (2004) 'Adjusting China’s Exchange Rate Policies', Policy Briefs in International Economics, (May), Institute for International Economics: Washington DC.

Heath, A. (2004) 'China Dashes G7 Hopes of Currency Revaluation', The Business, October 4, p. 1.

Higgins, M. and Klitgaard, T. (2004) 'Reserve Accumulation: Implications for Global Capital Flows And Financial Markets', Federal Reserve Bank of New York: Current Issues in Economics and Finance, 10 (September/October).

Hitchens, C. (2002) 'Imperialism. Superpower Dominance, Malignant and Benign', Slate.msn.com, December 10, http://slate.msn.com/id/2075621.

Hutton, W. (2002) The World We're In, London: Little, Brown.

Ikenberry, G.J. (1989) 'Rethinking the origins of American hegemony', Political Science Quarterly 104(3): 375-400.

Ikenberry, G.J. (2004) 'Illusions of empire: defining the new American order', Foreign Affairs 83(2): 144-154.

Kady, D. (2004) 'Defense: A Deficit Driver', CQ Weekly, January 17, pp. 154-156.

Kennedy, P. (1989) The Rise and Fall of the Great Powers: Economic Change and Military Conflict from 1500 to 2000, London: Fontana.

Keohane, R.O. (1984) After Hegemony: Cooperation and Discord in the World Economy, Princeton: Princeton University Press.

Labonte, M. and Makinen, G. (2004) 'Changing Causes of the US Trade Deficit', Congressional Research Service, October 12.

Labonte, M. (2005) 'Is the Current Account Deficit Sustainable', Congressional Research Service, December 13.

Levey, D.H and Brown, S.S. (2005) 'The overstretch myth', Foreign Affairs 84(1): 2-7.

Mann, C.L. (1999) Is the US Trade Deficit Sustainable?, Washington: Institute for International Economics.

Mann, M. (2004) 'The First Failed Empire of the Twenty-First Century', in D. Held and M. Koenig-Archibugi (eds.) American Power in the 21st Century, Cambridge: Polity Press, pp. 52-82.

McKinnon, R.I. (2005) 'Trapped by the International Dollar Standard', http://ideas.repec.org/a/ eee/jpomo/v27y2005i4p477-485.html.

Mead, W.R. (2004a) Power, Terror, Peace, and War: America's Grand Strategy in a World at Risk, New York: Knopf.

Mead, W.R. (2004b) 'America's sticky power', Foreign Policy 83(2): 46-53.

Miller, R. (2005) 'The Deficit: The Sky May Not Be Falling', Business Week, March 21, pp. 7-8.

Nixon, R.M. (1971) Public Papers of the Presidents of the United States, Washington DC: Government Printing Office.

Nye, J.S. (1990) Bound to Lead: The Changing Nature of American Power, New York: Basic Books.

Nye, J.S. (2002) The Paradox of American Power: Why the World's Only Superpower Can't Go It Alone, New York: Oxford University Press.

Office of Management and Budget (2005) Budget of the United States Government, Fiscal Year 2006: Historical Tables, Washington DC: Government Printing Office.

Pesek Jr, W. (2005) 'If China Shuns Dollar, Look Out US Bonds', January 28, www. bloomberg.com/apps/news?pid.

Peterson, P.G. (2004) 'Riding for a fall', Foreign Affairs 83(5): 111-125.

Peterson, P.G. (2005) 'Old Habits Must Change', The Banker 79(1): 12-13.

Reagan, R. (1990) An American Life, London: Hutchison.

Roach, S. (2004) The Funding of America, Morgan Stanley Dean Witter Global Economic Forum (August 23).

Rogoff, K. (2005) 'America's Current Account: A Deficit of Judgement', http://www.globalagen damagazine.com/2005/kennethrogoff.asp. 
Roubini, N. and Setser, B. (2004) The US as a Net Debtor: The Sustainability of External Imbalances, November, http: www.stern.nyu.edu/globalmacro/Roubini-Setser-US-ExternalImbalances.pdf.

Roubini, N. and Setser, B. (2005) Will the Bretton Woods 2 Regime Unravel Soon? The Risk of a Hard Landing in 2005-2006, Feb.2005, http:/www.stern.nyu.edu/globalmacro/.

Rubin, R., Orszag, P.R. and Sinai, A. (2004) 'Sustained Budget Deficits: Longer-Run US Economic Performance and the Risk of Financial and Fiscal Disarray', Allied Social Science Annual Meetings, The Andrew Brimmer Policy Forum 'National Economic and Financial Policies for Growth and Stability' (Jan 4).

Russett, B. (1985) 'The Mysterious Case of Vanishing Hegemony: or, is Mark Twain really dead?' International Organization 39(2): 202-232.

Samuelson, R.J. (2005) 'Bottom Dollar', Newsweek, March 21, pp. 41-48.

Schweizer, P. (2002) Reagan's War, New York: Doubleday.

Schwenninger, S.R. (2004) 'America's "Suez Moment”, The Atlantic Monthly (January/February): 129-130.

Seager, A. (2006) 'Scaremongers likely to be disappointed again', The Guardian, January 3, p. 21.

Setser, B. and Roubini, N. (2005) 'Our money, our debt, our problem', Foreign Affairs 84(4): 198.

Shaw, M. (2002) 'Post-imperial and quasi-imperial: state and empire in the global era', Millennium: Journal of International Studies 31(1): 109-127.

Snidal, D. (1985) 'The limits of hegemonic stability theory', International Organization 39(4): 579-614.

Stewart, H. (2005) 'Revaluing the Yuan is a Sign of Strength, not Weakness', The Observer, July 24, p. B3.

Stiglitz, J. (2002) Globalization and Its Discontents, New York: Norton.

Summers, L.H. (2004a) 'America Overdrawn', Foreign Policy, (July/August): 47-49.

Summers, L.H. (2004b) The United States and the Global Adjustment Process, Stavros S. Niarchos lecture, Institute for International Economics (March 23), www.iie.com/publications/papers/ summers0304.htm.

The Economist (2004) 'The Passing of the Buck?' (December 4): 77-80.

The Economist (2005a) 'Collywobbles', February 26, pp. 82-83.

The Economist (2005b) 'Wide Gap, Big Yawn', March 19, p. 94.

Torres, C. (2005) 'US 4th Quarter Current Account Deficit Grows to Record', http://bloomberg. com/apps/news/pid.

Wade, R. (2003) 'The invisible hand of the American empire', Ethics and International Affairs 17(2): 77-88.

Weisman, J. and Baker, P. (2005) 'After Bush Leaves Office, His Budget's Costs Balloon', Washington Post, February 14, p. A1.

Weller, C. (2004) 'The US Current Account Deficit: On An Unsustainable Path', New Economy 11(4): 243-248.

Zuckerman, M. (1998) 'A second American century', Foreign Affairs 77(3): 18-31. 